\title{
Research Article: Association between the characteristics with perception of the member farmers of Gram Panchayat about farm television
}

Article C
Received :
12.04.2017;
Revised :
09.06.2017;
Accepted :
22.06.2017

KeY WoRDS :

Farm television, Gram panchayat, Perception

\section{H.K. VERMA, PRADEEP YADAV AND KAILASH}

SUMMARY : The study was conducted to determine the socio-personal, economical, communicational and psychological characteristics of member farmers of Gram Panchayat and to explore the relationships between selected characteristics of the member farmers and perception of the member farmers of Gram Panchayat about farm television. Data were collected through interviewing during the year 2012 from randomly selected eight taluka of Anand districts of Gujarat with the sample size of 96 respondents they were member of Gram Panchayat. Results indicated that slightly less than one third of the respondents were in secondary education group. Medium level of age group, extension contact, scientific orientation, risk orientation, economic motivation whereas farming experience, innovativeness were high and land holding were low level group. Majority of the member farmers had membership in one organization. The independent variables like, extension contact and scientific orientation had positive and highly significant correlation, whereas education, social participation, economic motivation, risk orientation and innovativeness had positive and significant correlation with perception of member farmers of Gram Panchayat about farm television whereas farming experience had negatively significant correlation with perception of member farmers of Gram Panchayat about farm television.

How to cite this article : Verma, H.K., Yadav, Pradeep and Kailash (2017). Association between the characteristics with perception of the member farmers of Gram Panchayat about farm television. Agric. Update, 12(3): 357-360; DOI : 10.15740/HAS/AU/12.3/357-360.

\section{Author for correspondence :}

\section{H.K. VERMA}

Agricultural Technology Application, Research

Institute, CAZRI

Campus, JODHPUR

(RAJASTHAN) INDIA

Email:hemantverma478@ gmail.com

See end of the article for authors' affiliations 